Review

\title{
The Three Dimensional Role of Education for Women Empowerment
}

\author{
Yilikal Muche Engida \\ Department of Gender and Development Studies, College of Social Science and Humanities, University of Gondar, Ethiopia
}

Article history

Received: 02-09-2020

Revised: 13-03-2021

Accepted: 16-03-2021

Email: Yilikalm2000@Gmail

\begin{abstract}
Education is the most essential prerequisite for any person and a constitutional right. It helps the person minimize inequality and plays a central role in human development that influences the overall growth of the social economy. The empowerment of women is the key mechanism for achieving gender equality, which is apprehended as meaning that individual' obligations, freedoms and opportunities do not depend on whether they are born female or male. All relevant and accessible documents discussed in relation to the role of women empowerment in education have been listed and record analysis has been conducted. Books, papers and articles on policy and tactics were the key sources used in the search for the text. Education is one of the most effective ways of encouraging women to engage fully in the growth process with the awareness, skills and self-confidence available. Training also allows women to manage their lives, have greater bargaining power and be happier mothers with stronger spousal relationships. Education helps the exercise of women's rights and responsibilities as members of their society. It gives them the chance to make more meaningful decisions in terms of political engagement and making choices about life. Thus, education can benefit from building self-confidence, self-efficacy, decision-making power and increase gender parity in organizations and institutions.
\end{abstract}

Keywords: Education, Women Empowerment, Personal, Relational and Social Empowerment

\section{Introduction}

For any person, education is the most important prerequisite and constitutional right. It assists individuals in reducing inequality and plays a critical role in human development, which has an impact on the overall growth of the social economy. Improved health, nutritional status, economic growth, population reduction, empowerment of the weaker sections and society as a whole are all benefits of increased literacy and education (Khatri, 2016). Women's empowerment refers to the process of improving women's economic, economic, cultural and political status within society, which has traditionally been oppressed and ignored. According to numerous studies, women are more likely than men to spend a significant portion of their household income on their children's health and education. When women are properly empowered to obtain, accumulate assets and boost their financial security, they create capacity for industrial support and stimulate economic development by creating new jobs and expanding a country's talent pool and human resources available (Hasin and Musa, 2018).

Women's empowerment is the cornerstone for achieving gender equality, which is characterized as individuals' responsibilities, rights and opportunities being independent of their gender (Hasin and Musa, 2018). Women's empowerment as a decision-making skill, strategic lifestyle choices and changes in welfarerelated programs for women are all examples of women's empowerment. Education is the most potent tool for improving the world. Empowering women and equipping countries for all-around economic development, according to (Ruqia, 2018), is a crucial point. As women plan for fair access to education and equal rights, they continue to engage in economic activity.

Education is one of the most significant factors in improving women's living conditions. There are several disadvantages to not educating women, including less jobs, lower family income, the possibility of exploitation and a country's overall limited economic development. Unused human capital, especially in developed 
countries, are a source of concern for women. They develop the power and voice to make choices and effect meaningful social change as a result of their education (JhA, 2014). Education is important for everyone, but it is especially important for girls and women. This is because not only is education an entrance point to success but also because women are educational successes within the family and through generations that have major ripple effects. The most powerful tool for enhancing the role of women in society is education (Srivastava, 2014).

The Education 2030 declaration represents a dedication to ensuring equitable access to high-quality education and lifelong learning for all people. The Sustainable Development Goal (SDG) 4.5, which specifically calls for the elimination of gender disparities in education and equitable opportunities for all, as well as the wider Sustainable Development Plan for 2030, strengthens and amplifies the clear connection between gender equality and education. To achieve gender equality, a rights-based approach is required, ensuring that both girls and boys, women and men, have equal access to and completion of education cycles, as well as equal empowerment in and through education. "If you educate a man, you educate a person, but if you educate a woman, you educate a family (nation)" we learn from a common African proverb (Suen, 2013). Training can develop the abilities of an individual and that person can bring about positive social change in society (Chavez, 2015).

Despite mounting evidence of the value and effect of educating girls, a significant portion of our society, especially in developing countries, takes little to no action to educate this vital demographic. More than 63 million girls are out of school worldwide, with $47 \%$ of them never expected to return, compared to $35 \%$ of boys. Women account for two-thirds of the world's illiterate adult populations (UNESCO, 2016). The human rights model was developed by UNESCO and UNICEF. This rightsbased approach states that every citizen is entitled to an education, including every child, even though it is not possible to be sure that this education will pay off in terms of human capital. Entry to quality education should be available to every child with dignity and respect and without discrimination (UNICEF, 2007).

As described above the importance of education in women's empowerment is enormous for women and for the economy of the country. In order to represent the claim, the investigator reviewed various papers by considering the particular benefits of education for women. The role of education in three aspects of empowerment has been addressed in this study. These are personal empowerment, relational empowerment (relationship with others, bargaining power and decisionmaking) and social empowerment (self-awareness selfconfidence and self-efficacy) (where women are identified using specific indices). The document reviewer used the right-based approach in which access to education should be provided to every citizen. The explanation for the researcher's preference for this model is that women's illiteracy is due to access to education.

All applicable and accessible documents discussed in relation to the role of women empowerment in education have been listed and record analysis has been conducted. Books, papers and articles on policy and tactics were the key sources used in the search for the text. After an initial evaluation of their titles and abstracts or summary, detailed analyses of the described documents were organized. Using recording research, both quantitative and qualitative data were comprehensively and comparatively analyzed. Specific qualitative and quantitative studies available on the issues are evaluated based on the context in which different conations are accessible.

\section{Women and Education}

The right to education has been recognized as a "multiplier right" in international law and policy, allowing right-holders to exercise a wide range of human rights when fully realized (Wodon et al., 2018). The international focus on girls' education recognizes its catalytic role in promoting substantive equality between men and women, as well as a means to improve global health, economic, political, cultural and social development outcomes (Tomasevski, 2003). In practice, however, there are numerous obstacles to the realization of the right to education globally. While some of these barriers apply to both boys and girls, there are specific hurdles that girls must overcome in many contexts in order to equally enjoy their human rights to, within and through education (UN, 1999).

In 18 low-and middle-income countries, the World Bank analyzed the effects of educating girls to at least a secondary level. The most significant results were beneficial to the children, their families, culture and the economy. Universal secondary education has been shown to contribute to empowerment and improvement (Wodon et al., 2018). Investing in girls' education has long been held up as an antidote to the manifold challenges of the developing world. Researchers, politicians and celebrities have all championed the value both inherent and instrumental of girls' education. (Herz et al., 2004).

According to (Evans et al., 2021), rises in women's education have been followed by increases in men's education in most countries. Over the last 50 years, the trend of major changes for women has been surprisingly consistent all over the world. Also countries with the smallest gains in women's education have seen substantial progress in most areas. Although women's education increased significantly across the world between 1960 and 2010, most countries still have a gender gap in educational attainment. The gender gap narrowed in 94 countries during that period, but it expanded in 32 others. 


\section{Women Empowerment Index}

In 1995, United Nations Development Program (UNDP) launched two major indexes, the Gender-related Development Index (GDI) and the Gender Empowerment Metric, as a groundbreaking approach (GEM). GDI is a gender-sensitive extension of HDI that calculates the differences in life expectancy, education and income between men and women (Klasen, 2006).

Bhattacharya and Banerjee (2012) attempted to concentrate on the latent essence of empowerment as demonstrated by their increased capacity. They see empowerment as a mechanism involving oppressive power, questioning power and imaginative power. As a result, the degree of deliberate involvement in decision-making to secure and improve one's own well-being will be a strong predictor of empowerment on an individual level.

\section{Women Empowerment Indicators in Education}

Education metrics are one of the most significant indicators of women's status and gender equality. Training empowers girls and women by providing them with the skills they need to make educated decisions in their daily lives and to achieve bargaining power. In terms of securing money, a mother's education has a greater effect on her children than a father's (UNFPA, 2000). Women with higher levels of education have lower fertility rates, better nutrition and use of health care for themselves and their children (Vos, 1996).

Education indicators document both absolute and measured amounts (e.g., the number of students and teachers) (e.g., percentages, rates, ratios, absolute gender gap and gender parity index). Governments and international organizations often use the absolute gender gap and the gender parity index to measure gender disparities in education. However, since the origins of data patterns cannot be readily apparent, these calculations may lead to data misinterpretation. For example, the gender gap may narrow through a decline in boys' school enrollment (with the female rate remaining constant), an increase in female enrollment faster than the male rate or a decline in enrollment of both genders with the male rate declining faster. Therefore, these measurements fail to capture the absolute level of achievement. Countries' averages can mask sub-national variation and overlook disparities among different classes, racial groups and regional populations. To capture gender equity and absolute achievement, UNDP developed a gender-equity-sensitive indicator (UNESCO, 1997).

There are two main types of education metrics. Literacy, educational achievement, access to education and school attendance are among the first group of population characteristics. Enrollment, enrollment, educational facilities and curricula are examples of educational system interventions (Beck, 1999).
Each education indicator has a distinct feature. The aggregate stock of available human capital is calculated by adult literacy rates and average years of schooling measures. School enrollment ratios equate the ability of a school system to the number of students who are eligible to attend. The level of access to education is expressed in school enrollment rates. Survival rates, completion rates, repeat rates and dropout rates are used to determine an education system's internal productivity and forecast educational cycle flows. School life expectancy measures the probability of a child being enrolled in school at any particular age assumed equal to the current enrollment ratio at that age School survival expectancy predicts the number of years of school a child already in school can expect to receive (UNESCO, 1997).

All of these indicators provide a different measure of women's empowerment and serve as benchmarks for initiatives aimed at achieving gender equity and equality in education. The percentage of female teachers, for example, will indicate how influential female teachers are in inspiring young women to continue their education. A higher proportion of female teachers may encourage parents to educate their daughters, especially in countries where women have a lower socioeconomic status (UNESCO, 2003).

Education is an important tool for achieving gender equality and poverty reduction. It improves overall social welfare by extending life expectancy, reducing crime and promoting social cohesion (Vila, 2000). Female education is critical for breaking the cycle of poverty and balancing wealth distribution, which in turn helps to maintain social stability. Women with more education have better access to resources, more job opportunities and better ability to make informed decisions about their health, marriage and parenting. Other social benefits (e.g., decline in infant mortality and HIV/AIDS infections and greater educational opportunities for children) are positively affected by female education, particularly secondary education. As macroeconomic studies indicate, marginal returns on the education of girls are consistently higher than those of boys are and are even greater when educational attainment of the next generation is considered (Hill and King, 1995).

\section{Gender Responsive Education System}

"Gender-based discrimination remains one of the most intractable constraints to realizing the right to education," according to the 2000 Education For All (EFA) Framework for Action. Education for All will not be possible unless this barrier is overcome." Fifteen years later, although the context has changed, attention to gender issues remains a key component of the global agenda. At the 2015, World Education Forum in Incheon, Korea, representatives issued a declaration reaffirming the vision of EFA initiated in Jomtien in 
1990 and reiterated in Dakar in 2000. The Education 2030 declaration articulates a continued vision of achieving inclusive and equitable quality education and lifelong learning for all. This vision explicitly recognizes the importance of "gender equality in achieving the right to education for all” (UNGEI, 2017).

In order to address existing gender inequalities and ensure that children have equal opportunities in education and employment in the future, it is critical to ensure that boys and girls have equal access to education and that gender-sensitive education is used in the classroom. Gender-sensitive pedagogy helps children learn in a safe and accepting environment. Students are encouraged to challenge existing gender stereotypes and pursue their passions regardless of societal gender roles (Korenius, 2018).

\section{The Three-Dimensional Role of Education for Women Empowerment}

\section{Dimension One: Personal Empowerment}

Education is one of the most effective ways to encourage women to fully participate in the growth process by providing them with the knowledge, skills and self-confidence they need. However, while education is undeniably a key factor contributing to empowerment, the two do not inherently go hand in hand (Uwakwe et al., 2008).

Women's education has cognitive benefits for their children. Women's quality of life is improved by improved cognitive skills, which also contribute to other benefits. One indicator of this is that educated women are better able to make health-related decisions for themselves and their children. Increased female political engagement is also linked to cognitive abilities (Chandra, 2018). Education boosts "people's selfconfidence and encourages them to pursue better jobs, so they can work shoulder to shoulder with men." They participate in public debates and make demands on the government for health care, social security and other benefits (Mercy and Rani, 2019). Similarly, according to (Stromquist, 2015), Formal education explores the awareness and, indirectly, the psychological aspects of empowerment by improving the students' sense of selfesteem, efficiency and expectations for the future of life.

Girls who receive an education are more likely to marry later and have smaller, healthier families. Women who are trained may recognize the importance of health care for themselves and their children and know how to obtain it. Education enables girls and women to become more aware of their rights and to develop the courage to assert them. Despite this, women's literacy rates in most developed countries are significantly lower than men's (Girman, 2012). Encouraging girls to use their own voices and ideas about human rights in a secure and supportive environment, they can build their own sense of security and dignity, despite living in conditions where patriarchal pressures and economic insecurity could threaten their human rights (Gervais, 2011).

\section{Dimension Two: Relational Empowerment}

According to research, increased social contact among female program beneficiaries, community members and leaders appears to increase communication and that this contact may encourage the exchange of information and cause major behavioral and attitudinal changes' (Vakis et al., 2011). A large body of evidence suggests that educated women are more interested in making informed decisions about their personal lives (Stromquist, 2015).

Educated women are more likely to participate in public participation and attend political meetings and there have been several cases where qualified women in developing countries have benefited from political campaigns. Data also shows that highly educated women's countries have a higher likelihood of democratic governance (Chandra, 2018). A welleducated woman can fit into any class or culture, freely express her views and contribute to the social growth of her community. Training also helps women balance their lives, have better bargaining power and be better mothers with better relationships with their husbands (Magaji, 2014)

Mothers become more mindful of their duties to their children as a result of their schooling. Children grow and learn quickly when their mothers are well-trained. Nigerian women have led their children's education and, in the process, have often denied themselves basic necessities such as good food, decent clothing, great opportunities and comfort in order to educate their children. Mothers are willing to make every sacrifice for their children and some are willing to risk anything for their children's education because they recognize the importance of education (Magaji, 2014). In addition, an educated mother's greater influence in household negotiations may allow hereto-secure more resources for her children (Benedicta, 2011)

\section{Dimension Three: Social Empowerment}

United Nations Development Program (UNDP) adopted two key indexes, the Gender-related Development Index (GDI) and the GenderEmpowerment Indicator, in 1995, in a ground-breaking approach (GEM). GDI tracks gender gaps in life expectancy, schooling and jobs and can be thought of as a gender-responsive extension of HDI (Klasen, 2006).

Women's empowerment can be used to counter women's absolute status or relative gender discrimination. Accepting utter measures is expected for certain aspects of empowerment. Women's right to travel 
openly, for example, is vital to their freedom, regardless of whether men can do so as well. That is, ranking women as more influential than men does not reflect their lived life, in which both men and women have restricted freedoms. Instead, it is important to document the utter condition of women. Other facets of women's empowerment are better analyses with respect to men, however (Lindberg et al., 2015).

Training helps women to live a decent human life and makes them conscious of their rights in society. They will, however, obtain a quick and easy legal battle against the most prevalent forms of violence against women, such as dowry, forced prostitution, female feticide, child marriage and so on (Basheer, 2018). According to (Magaji, 2012), educating women as members of society helps them to exercise their rights and obligations. It helps them to make more informed decisions in terms of political participation and life choices.

Women's education, according to (Chandra, 2018), contributes significantly to social development. Lower birth rates and child mortality rates, as well as lower maternal mortality rates, are some of the most important social benefits. Closing the gender gap in education also improves gender equality, which is seen as important in and of itself, as it guarantees equal rights and opportunities for all people.

Women's education, even at the most basic level, has the potential to increase their participation in the political process as citizens and legislators. As previously mentioned, this applies to raising the level of democratic governance by making women less corrupt. It also strengthens how women's needs are represented in policymaking. According to recent studies, women's participation in government is growing in areas such as education, protection, drinking water supply and coverage of crime against women (Clots-Figueras, 2012).

Access to justice is vital to the women's political empowerment component of choice, based on the idea that women's rights are human rights. If women are unable to challenge challenges to their enforcement of routine activities in everyday life in the justice system, therefore customary practices that restrict women's options will continue to exist. To illustrate that legal rights are less important if a judicial system does not enforce fair rights for women to own property or inherit wealth in its decisions (Benschop, 2002).

For nearly five years, the case study on Burundi assessed a 30 percent women's participation quota in political institutions. Given that quotas raised the number of women in decision-making bodies at all levels, including local government, it seems that this did not inevitably result in substantive and effective women's representation or a noticeable reduction in gender inequality. Women, especially those living in rural and peri-urban areas, continue to face significant challenges such as poverty, lack of access to land and property, analphabetism and heavy domestic workloads (International Warning, 2012).

\section{Conclusion and Recommendations}

Education is the most important prerequisite and constitutional right for any person. It helps the individual to minimize inequality and plays a central role in human development that affects the social economy's overall growth. Higher levels of literacy and education contribute to better health outcomes, nutritional status, economic development, population control, poorer sections' empowerment and community. In addition, its value was divided into three dimensions. This is personal empowerment, relational empowerment (relationship with others, negotiation and decision-making power and social empowerment (self-awareness self-confidence, self-efficacy) (where women are found by using different indices). Based on the checked documents, women may also benefit from three-dimensional schooling.

Upon concluding this research, the researcher proposed that access to education for all, especially for women, should be accessible to all. Since it educates society and makes a great contribution to the growth of a nation if women are taught.

\section{Acknowledgement}

I am indebted to many individuals who have contributed to the preparation of this review. First of all, my gratitude goes to Alemeneh Getaneh for his critical and constructive comments and suggestions he gave me throughout the research process. His contribution was immense for the development of the research article that all things go hand in hand up to the desired output took place. Second my precious thanks are also to Mr. Eyayu Kaseye and Genanew Jenberu in helping me how I can run with my time in doing the research article and all their help in my work. Finally, the gratitude goes to $\mathrm{Mr}$. Tezera Tazebew that he was behind me in helping me how and what needs to be and how the data I used was searching for different materials.

\section{Ethics}

The researcher had correctly addressed the documents need to get information about the role of education for women empowerment. In addition the addressed articles, reported and documents had vigorously putted under the reference part of the article.

\section{References}

Basheer, R. P. (2018). Empowerment of women through Education: A Special Reference to Mahatma Gandhi. International J Res Anal Rev, 5(3), 1756-1758. http://ijrar.com/upload_issue/ijrar_issue_1535.pdf 
Beck, T. (1999). Using Gender-Sensitive Indicators-A Reference Manual for Governments and Other Stakeholders. Commonwealth Secretariat.

Benedicta, U. (2011). Female gender in Professional Education. In FIG Working Week.

Benschop, M. (2002). Rights and reality: are women's equal rights to land, housing and property implemented in East Africa?. Un-Habitat.

Bhattacharya, J., \& Banerjee, S. (2012). Women empowerment as multidimensional capability enhancement: An application of structural equation modeling. Poverty \& Public Policy, 4(3), 79-98.

Chandra, B. B. (2018). Role of Education in Empowering Women: A Case Study. Asian Review of Social Sciences, Volume 7(1).

Chavez, A. A. (2015). Which way out of poverty? The Human Capital versus Human Capabilities approaches. Maskana, 6 (1), 19-25. https://publicaciones.ucuenca.edu.ec/ojs/index.php/ maskana/article/view/443

Clots-Figueras, I. (2012). Are female leaders good for education? Evidence from India. American Economic Journal: Applied Economics, 4(1), 212-44. https://www.aeaweb.org/articles?id=10.1257/app. 4.1.212

Evans, D. K., Akmal, M., \& Jakiela, P. (2021). Gender gaps in education: The long view. IZA Journal of Development and Migration, 12(1). https://content.sciendo.com/view/journals/izajodm/1 2/1/article-20210001.xml

Gervais, C. (2011). On their own and in their own words: Bolivian adolescent girls' empowerment through non-governmental human rights education. Journal of Youth Studies, 14(2), 197-217. https://www.tandfonline.com/doi/abs/10.1080/1367 6261.2010 .506528

Girman, S. (2012). Education, Training and Professional Development for Women 11th Edition. British library catalogue publishers, Mexico

Hasin, F., \& Musa, H. H. (2018). Women Empowerment Model: Strategies To Overcome Challenges Research Article Special Issue. Journal of Fundamental and Applied Science, 10, 1068-6083.

Herz, B., Herz, B. K., \& Sperling, G. B. (2004). What works in girls' education: Evidence and policies from the developing world. Council on foreign relations.

Hill, M. A., \& King, E. (1995). Women's education and economic well-being. Feminist Economics, $1(2), \quad 21-46$. https://www.tandfonline.com/doi/abs/10.1080/714 042230

JhA, B. (2014). Education: An instrument to enhance women empowerment and inclusive growth.
Khatri, R. (2016). The role of education towards women empowerment in India. international journal of advanced research, volume 4 No.11.

Klasen, S. (2006). UNDP's gender-related measures: some conceptual problems and possible solutions. Journal of Human Development, 7(2), 243-274. https://www.tandfonline.com/doi/abs/10.1080/1464 9880600768595

Korenius, S. (2018). Gender sensitive education-A literature review of relevant toolkits for secondary school teachers in Eritrea.

Lindberg, S., Sundström, A., \& Wang, T. (2015). Women's Political Empowerment: A New Global Index, 1900-2012. University of Gothenburg, VDem Institute.

Magaji, R. J. (2012). Adult and non-formal education: A tool for women empowerment and national development". Zaria Educator. A Journal Publication of Association of Nigeria Educators volume 7(1).

Magaji, R. J. (2014). The Role of Women Education in the Empowerment of Women for National Development. Multidisciplinary Journal of Research Development Volume 22(1).

Mercy, S., \& Rani, K. (2019). Women Empowerment- A Tool of National Development. Journal of Emerging Technologies and Innovative Research (JETIR), Volume 6(3).

Ruqia, M-u-D. (2018). Role of education in women empowerment. International Journal of Academic Research and Development. volume 3(1).

Srivastava, N. (2014). Education: A path to women empowerment (issues and challenges). International Journal of Management Research and Reviews, 4(10), 1007. https://search.proquest.com/openview/e3dc74c8faad 63b2fed05040c42482d6/1?pqorigsite $=$ gscholar $\& \mathrm{cbl}=2028922$

Stromquist, N. P. (2015). Women's E mpowerment and E ducation: linking knowledge to transformative action. European Journal of Education, 50(3), 307-324.

Suen, S. (2013). The education of women as a tool in development: challenging the African maxim. http://journals.ed.ac.uk/hydra/article/view/720

Tomasevski, K. (2003). Education denied: Costs and remedies. Zed books.

UN. (1999). Committee on Economic, Social and Cultural Rights, General Comment no. 13 (1999), para. 1, 'Education is both a human right in itself and an indispensable means of realizing other human rights .

UNESCO. (1997). Gender-Sensitive Education Statistics and Indicators: A Practical Guide. Montreal, Canada: UNESCO Division of Statistics.

UNESCO. (2016). Global education monitoring report: Education for people and planet: Creating sustainable futures for all. Paris, France: Author. 
UNESCO. 2003. EFA Global Monitoring Report 2003/4: Gender and Education for All: The Leap to Equality. Paris, France: UNESCO.

UNFPA. (2000). "Promoting Gender Equality: Empowering Women through Education.” http://www.unfpa.org/gender/empowerment2.htm

UNGEI. (2017). Guidance for Developing GenderResponsive Education Sector Plans. New York, NY. United Nations Girls' Education Initiative.

UNICEF. (2007). A human rights-based approach to education for all. United Nations Children's Fund.

Uwakwe, C. U., Falaye, A. O., Emunemu, B. O., \& Adelore, O. (2008). Impact of decentralization and privatization on the quality of education in subSaharan Africa: The Nigerian experience. European Journal of Social Sciences, 7(1), 160-170.
Vakis, R., Muñoz, A. M. \& Coello, B. (2011). A Gender (R) Evolution In The Making: Expanding Women's Economic Opportunities In Central America: A Decade In Review (Washington, D.C., World Bank).

Vila, L. E. (2000). The non-monetary benefits of education. European Journal of Education, 35(1), 21-32. https://www.jstor.org/stable/1503615?seq=1

Vos, R. (1996). Educational Indicators: What's To Be Measured?. Integration and Regional Programs Department, Inter-American Institute for Social Development, Inter-American Development Bank.

Wodon, Q., Montenegro, C. E., Nguyen, H., \& Onagoruwa, A. (2018). Missed Oportunities: The High Cost of Not Educating Girls. http://repositorio.minedu.gob.pe/handle/20.500.1279 9/6624 